ЕКОНОМІКА ТА УПРАВАІННЯ ПІАПРИЕМСТВАМИ

Удк 338.48:379.8

DOI: https://doi.org/10.32851/2708-0366/2021.8.3

\author{
Бойко В.О. \\ кандидат економічних наук, доцент, \\ доцент кафредри готельно-ресторанного \\ та туристичного бізнесу й іноземних мов, \\ Херсонський державний аграрно-економічний університет \\ ORCID: https://orcid.org/0000-0002-8032-5731
}

Boiko Viktoriia

Kherson State Agrarian and Economic University

\title{
ГЛЕМПІНГ - НОВИЙ ТРЕНД ІНДУСТРІЇ ГОСТИННОСТІ
}

\section{GLAMPING AS A NEW TREND IN HOSPITALITY INDUSTRY}

Глемпінг як напрям туристичного та готельного бізнесу в Украӥні отримав розвиток в останні декілька років. Сам термін означає відпочинок на природі з усіма зручностями, включаючи гарячий душ, Інтернет, смачну їжу. Можливість змінити обстановку, приділити увагу рідним і близьким, відкрити нові куточки рідного краю надихає туристів на поїзкки в найбільш незвичайні місия, а витрати на такий тур можуть бути набагато нижчі, ніж на подорож у зарубіжні краӥни. У статті розглянуто поняття, принципи й концепцію глемпінгу як нового тренду індустрії гостинності, його основні види, виявлено проблеми та перспективи розвитку. Підкреслено важливість інновацій та пошуку нових креативних рішень у створенні ексклюзивного туристичного продукту в природоохоронних територіях. Сформульовано висновки стосовно забезпечення подальшого розвитку туристичної і готельної діяльності у стилі глемпінгу.

Ключові слова: глемпінг, туристичний та готельний бізнес, форми відпочинку, сфера послуг, індустрія гостинності.

Глемпинг как направление туристического и гостиничного бизнеса в Украине получил развитие в последние несколько лет. Сам термин означает отдых на природе со всеми удобствами, включая горячий дуи, Интернет, вкусную еду. Возможность сменить обстановку, уделить внимание родным и близким, открыть новые уголки родного края вдохновляет туристов на поездки в самые необычные места, а затраты на такой тур могут быть намного ниже, чем на путешествие в зарубежные страны. В статье рассмотрень понятие, принципы и концепция глемпинга как нового тренда индустрии гостеприимства, его основные виды, выявлены проблемы и перспективы развития. Подчеркнута важность инновачий и поиска новых креативных решений в создании эксклюзивного туристического продукта в природоохранных территориях. Сформулированы выводы по обеспечению дальнейшего развития туристической и гостиничной деятельности в стиле глемпинга.

Ключевые слова: глемпинг, туристический и гостиничный бизнес, формы отдыха, сфера услуг, индустрия гостеприимства.

Global challenges and the COVID-19 pandemic have become an incentive for the development and active use of new trends and efficient competitive types of tourism services. Tourism has become more family-oriented and eco-friendly, it is safer to travel around the country with a less number of people and large territories, and there is no need to keep self-isolating after coming back. One of such relatively new trends in tourism activities, which has been used for more than ten years, is outdoor leisure in glamps. Glamping as a trend in tourism and hotel business in Ukraine has been developed over the past several years. The term itself means leisure in natural 
settings with all conveniences including hot shower, Internet and tasty food. The possibility to change the environment, pay attention to family and relatives, discover new places of the native country inspires tourists to travel to unusual places, and expenses for such journeys can be much lower than for travelling abroad.

The purpose of the study is to substantiate the prospects of developing hotels in the style of glamping as a new trend in hospitality industry under conditions of a market economy. In order to achieve the aim, we set the following tasks in the process of the research: to present theoretical generalization of the preconditions and approaches to the development of glamping in Ukraine at the present stage; to identify and analyze the main factors that have the most significant impact on the current state of glamping development; to determine the role of this business and its function in the development of the national economic complex of the country under conditions of market relations. The paper looks at the concept, principles and conception of glamping as a new trend in hospitality industry, its basic types and identifies problems and prospects of its development. The study underlines the importance of innovations and search for new creative decisions in developing an exclusive tourism product in nature reserves. It presents conclusions about maintaining further development of tourism and hotel activity in the style of glamping.

Key words: glamping, tourism and hotel business, formula of leisure, service sector, hospitality industry.

Постановка проблеми. Глобальні виклики та пандемія COVID-19 стали поштовхом до розвитку й активного використання нових трендів та ефективних конкурентоспроможних форм туристичних послуг. Туризм сьогодні став більш сімейним та екологічним, безпечніше стало мандрувати всередині країни, де менше людей, велика територія і не потрібно дотримуватись самоізоляції після повернення. Одним із таких достатньо нових напрямів туристичної діяльності, який у світі функціонує вже більше десяти років, є відпочинок у глемпах на природі. Для розвитку глемпінгу у нашій країні є всі передумови, зокрема наявність значної кількості мальовничих природних місць та різноманіття ландшафтного середовища, доступність до них, тобто шляхи сполучень, й активні люди на місцях, які надаватимуть туристам послуги. Відповідно, це може бути предметом подальших досліджень розвитку глемпінгу, а також пошуку нових креативних рішень у сфері гостинності.

Аналіз останніх досліджень і публікацій. Дослідженню проблем розвитку нових форм відпочинку у туристичному та готельному бізнесі, зокрема глемпінгів, присвячено низку праць науковців. І.В. Давиденко [1] розглядає глемпінг як нову перспективну форму організації екотуризму. В.О. Бойко [2-5] характеризує екологічний туризм як напрям зеленої економіки, розглядає сучасні тенденції і перспективи його розвитку в Україні в умовах посилення глобалізаційних процесів. Для ефективного розвитку екологічного туризму в Україні має сенс запозичення прикладу європейської туристичної практики [6; 7], а також розвиток таких його форм, як природні парки, екостежки, екокурорти, екокотеджі та глемпінги [8]. О.В. Олійник та співавтори [9] стверджують, що запровадження глемпінгів дасть змогу вирішити питання комфортного відпочинку споживачів у гармонії з природою, при цьому природоохоронні території України отримають нові економічні можливості за рахунок туристичного сектору. Г.М. Тарасюк зі співавторами [10] доводить, що глемпінги та агроготелі можуть стати перспективними, бо поєднують комфорт та повагу до довкілля, а також навчать догляду за господарством та приготуванню місцевих страв. Питання щодо розвитку глемпінгу як нової форми здійснення екотуристичної діяльності залишаються маловивченими, наукові праці з цієї проблематики практично відсутні.

Формулювання цілей статті. Метою статті є обгрунтування перспектив розвитку готелів у стилі глемпінг як нового тренду індустрії гостинності в умовах ринкової економіки. Для досягнення мети в процесі дослідження були поставлені такі завдання, як представлення теоретичного узагальнення передумов та підходів до розвитку глемпінгу в Україні на сучасному етапі; виявлення та аналіз основних факторів, що мають найбільш значний вплив на сучасний стан розвитку глемпінгів; визначення ролі цього 
бізнесу, його функції у розвитку національного господарського комплексу країни в умовах ринкових відносин.

Виклад основного матеріалу. «Глемпінг» дослівно 3 англійської перекладається як «гламурний кемпінг» (поєднання слів “glamur” та “camping”), а на практиці це легкі комфортабельні будиночки або шатра. Це відносно новий формат відпочинку, орієнтований на тих, хто хоче побути поближче до природи, але з комфортом рівня готелю. Першими глемперами без перебільшення були ще середньовічні королі, які під час військових походів розбивали величезні шатра. Звісно, такі похідні намети мали усе, що необхідно для комфорту короля та його наближених осіб. Найбільшої популярності формат відпочинку в шатрі з комфортом набув у XIX ст. серед багатих любителів полювань, що вирушали в експедиції Африкою та Південною Америкою. В їх тимчасових помешканнях були не тільки комфортні ліжка, але й цілі бібліотеки та справжні чавунні ванни. Глемпінг у сучасному виді набув популярності в середині 2000-х pp. у Великій Британії, де організатори літніх фестивалів почали облаштовувати комфортні кемпінги для вибагливих відвідувачів. Рух потроху став розвиватися, й сьогодні по світі $є$ чимало місць, де можна зупинитися в оригінальних глемпах. В Україну цей формат відпочинку тільки приходить [11].

Ринок глемпінгу досить активно розвивається у світі. Сьогодні найбільші ринки це США, Британія та Австралія, загальний обсяг ринку становить \$3 млрд. Зараз понад п'яти мільйонів людей люблять відпочивати у глемпах. Хтось навіть не уявляє для себе вже іншого виду туризму. Прогнозується, що до 2025 р. світовий ринок глемпінгів досягне обсягу $\$ 4,3$ млрд. [12].

Сучасними трендами розвитку суспільства $є$ посилення взаємодії з навколишнім середовищем, зростання попиту на екологічне житло, одяг із натуральних тканин, їжа 3 органічних продуктів тощо. Завдяки усвідомленості та екологічній відповідальності більшість населення спрямовує свою діяльність у «природну» сферу, щоб організувати ведення екологічно чистого бізнесу. Перспективним напрямом для економіки України сьогодні є розвиток туристичного бізнесу, зокрема розвиток екоготельного i глемпінгового підприємництва [13].

Глемпінг передбачає відпочинок на природі, навіть у природоохоронних територіях, однак з усіма необхідними умовами для розміщення. Однак на відміну від готелів, глемпінги можна встановлювати будь-де, переміщувати 3 місця на місце, навіть туди, де заборонене будь-яке будівництво, що, очевидно, неможливо здійснити з готелями. Переваги глемпінгу полягають у тому, що, по-перше, він окупається набагато швидше готелю, а саме за 2-3 роки; по-друге, установка глемпінгу не вимагає ніякої дозвільної документації. Юридично глемп класифікується як звичайна палатка, його можна поставити практично де завгодно, хіба що варто узгодити це 3 лісництвом, якщо це глемпінг у лісі або заповіднику, або з підприємством, яке має це місце на балансі. Іноді за встановлення глемпу можуть стягувати відповідну плату. Крім того, установка глемпінгу не завдає шкоди навколишньому середовищу. Глемп - це конструкція з металу, дерева й тентової тканини ПВ [14].

Протягом останніх кількох років глемпінг став одним із тих брендів туристичної галузі, що набув великої популярності серед мандрівників. Поєднуючи слова «гламур» та «кемпінг», ця тенденція зросла, оскільки підйом масового туризму змусив більше людей сприйняти екологічний дух відповідальних подорожей. Згідно з Оксфордським словником, глемпінг - це «форма кемпінгу, що передбачає розміщення та зручності, розкішніші за традиційні кемпінги». Вперше це слово було використано у Сполученому Королівстві у 2005 р., але до словника було додано лише у 2016 р.

Зараз у світі налічується близько тисячі працюючих глемпінгів. За даними британського туристичного бюро Campingselection, ринок глемпінгів зростає на 21\% щорічно, за прогнозами, у 2021 р. його обсяг складе вже близько \$4 млрд. Глемпінг - 
це набагато більше, ніж гарний намет, і по всьому світі є безліч неймовірних напрямів: від популярних екоглемпінгів, трейлерного глемпінгу до антарктичного лакшері-табору на льодовику [14].

Південна частина нашої країни - одне з таких місць, яке має значний ресурс $\mathrm{i}$ робочий потенціал для розвитку всіх видів туризму. Питання розвитку готельного та туристичного бізнесу в Херсонській області, на наш погляд, надзвичайно важливі, зрештою, вони орієнтовані як на зовнішній, так і на внутрішній соціально-економічний розвиток. Херсонщина - унікальна територія для туризму, відпочинку та рекреації, яка має достатньо переваг для формування та розвитку потужного курортно-туристичного комплексу. Область має широкий вихід до Дніпровської водної магістралі, і це єдина з областей України, яка має вихід одночасно до двох морів, а саме Чорного i Азовського. Саме на Херсонщині розташовані єдина в Європі природна пустеля (Олешківські піски), найбільший у світі рукотворний ліс і навіть унікальні горні ландшафти посеред степу «Станіславські кручі» [3].

Коронавірус вніс суттєві зміни до планів відпочинку багатьох людей не лише для зовнішнього, але й для внутрішнього туризму. Громадяни України, для яких ціни відпочинку на морських і гірських карпатських курортах є зависокими, здійснюють подорожі відомими їм мальовничими місцями власними або орендованими автівками, маючи особисті намети для відпочинку та домашнє харчування замість готельних номерів, ресторанів і кафе [15]. Альтернативою традиційним формам відпочинку та ночівлі можуть стати комфортабельні глемпінги, що не поступатимуться за зручностями готелям. Однак, на відміну від готелів, глемпінги мають великі переваги, адже їх можна встановлювати будь-де, переміщувати з місця на місце без оформлення всіляких бюрократичних довідок, лише з дозволу органів місцевого самоврядування. Глемпінги можна встановлювати там, де заборонено будь-яке будівництво, що, очевидно, неможливо здійснювати з готелями та базами відпочинку.

Міністерством захисту довкілля та природних ресурсів України спільно з Асоціацією органів місцевого самоврядування «Єврорегіон Карпати - Україна» та національними природними парками було підготовлено проєкт «Глемпінги - створення ексклюзивного туристичного продукту в природоохоронних територіях». Особливістю проєкту є розвиток туризму на територіях природно-заповідного фонду, що не буде негативно впливати на природну екосистему. Саме глемпінги, як зазначили у Міністерстві, стануть тим поєднанням традиційних кемпінгів із комфортними умовами готельного типу для туристів.

Згідно з проєктом, комфортабельні кемпінги передбачено створити у Регіональному ландшафтному парку «Краматорський» (Донецька область), Національному природному парку «Синевир» (Закарпатська область), Національному природному парку «Сколівські Бескиди» (Львівська область) та Регіональному ландшафтному парку «Дністровський» (Івано-Франківська область). Цим проєктом планується підвищити ефективність використання туристичного потенціалу природоохоронних територій та створити ексклюзивний продукт для туризму, а саме облаштування глемпінг-локацій у мальовничих місцях України, що буде поштовхом для суттєвого зростання ії конкурентоспроможності серед передових туристичних держав.

Сьогодні у світі спостерігається тенденція до збереження природних ресурсів, оскільки вони не безмежні і вичерпні, тому розвиток екоготельної індустрії у вигляді глемпів, основна діяльність якої спрямована на збереження природних ресурсів, - це високоприбутковий бізнес, який здатен зробити значний внесок у зростання валового внутрішнього продукту за відносно низьких затрат та коротких термінів окупності.

Порівняно з іншими видами туризму у екологічного більш виражена соціально-економічна спрямованість [16-18], він може посісти вагоме місце в економіці будь- 
якого регіону та надати як природним територіям, так і місцевому населенню, зайнятому у цій сфері, нові економічні можливості.

Висновки. Сучасні люди, які звикли до численних зручностей міського життя i хочуть насолоджуватися виїзним дозвіллям, не готові залишатися без теплого ліжка, душу та електрики, тому для них є новий тип дозвілля - глемпінг, який поєднує переваги природи та цивілізаційні зручності. Перевагами цього виду бізнесу є низька конкуренція та відсутність ії в деяких регіонах; швидке погашення, незважаючи на значний обсяг інвестицій; відносна стійкість проєкту до несприятливих економічних тенденцій, а також можливість швидкої зміни концепції; перспективи розширення бізнесу завдяки залученню іноземних туристів. Ймовірними ризиками є вибір неправильного місця; поломка обладнання; збільшення частки постійних витрат; несприятливий клімат; зміна законодавчої бази та посилення регулювання у цій сфері діяльності.

Основною проблемою для розвитку глемпінгу в Україні є новизна концепції законодавства (в жодних нормативних актах цього не передбачено) та те, що українці не розуміють, що їм пропонують. У законодавчій базі України немає таких слів, як «глемпінг» та «глемп». Отримуючи сертифікат відповідності, глемп класифікується як намет. Це спричиняє непорозуміння між підприємцями та інспекторами. Коли інспектор бачить, що намет зареєстрований, але це справжня конструкція, хоч і легка, але досить велика порівняно з наметом, виникає певний дисонанс. Слід розуміти, що новий формат туризму додасть соціальну складову частину, розширить можливості для місцевих підприємців, а також допоможе у створенні нових робочих місць. Таке підприємство має бути унікальним, незвичним та оригінальним і мати усі характеристики комфортного життя.

\section{Список використаних джерел:}

1. Давиденко І.В. Глемпінг як перспективна форма розвитку екотуризму. Науковий вісник Міжнародного гуманітарного університету. 2017. Вип. 26. С. 10-13.

2. Бойко В.О. Екологічний туризм як складова зеленої економіки. Ефективна економіка. 2021. № 4. URL: http://www.economy.nayka.com.ua/?op=1\&z=8773. DOI: 10.32702/2307-2105-2021.4.73 (дата звернення: 23.07.2021).

3. Boiko V.O. Green tourism as a perspective direction for rural entrepreneurship development. Scientific approaches to modernizing the economic system: vector of development: collective monograph. LvivToruń : Liha-Pres, 2020. P. 1-18. DOI: https://doi.org/10.36059/978-966-397-189-6/1-18.

4. Бойко В.О. Сільський зелений туризм в Україні: проблеми та перспективи. Агросвіт. 2020. № 22. C. 58-65. DOI: 10.32702/2306-6792.2020.22.58.

5. Бойко В.О. Розвиток зеленого туризму у південному регіоні. Підприємниитво в аграрній сфері: глобальні виклики та ефективний менеджмент : матеріали I Міжнародної науково-практичної конференції : у 2 ч. (12-13 лютого 2020 р.). Запоріжжя : ЗНУ, 2020. С. 65-68.

6. Kyrylov Y., Hranovska V., Boiko V., Kwilinski A., Boiko L. International Tourism Development in the Context of Increasing Globalization Risks: On the Example of Ukraine's Integration into the Global Tourism Industry. Journal of Risk and Financial Management. 2020. № 13 (12). P. 303.

7. Lyulyov O., Us Y., Pimonenko T., Kwilinski A., Vasylieva T., Dalevska N., Polcyn J., Boiko V. The Link between Economic Growth and Tourism: Covid-19 Impact. Proceedings of the 36th International Business Information Management Association (IBIMA) 4-5 November 2020 /S. Khalid, S. Soliman (ed.). Granada : IBIMA Publishing, 2020. P. 8070-8086.

8. Бойко В.О., Драгота І.П. Глемпінг - ексклюзивний туристичний продукт сьогодення. The I International Science Conference on Multidisciplinary Research (January 19-21, 2021). Berlin, Germany, 2021. P. 208-210.

9. Олійник О.В., Мостенська Т.Л., Тарасюк Г.М., Чагайда А.О. Перспективи розвитку готелів у стилі глемпінг в Україні. Економіка, управління та адміністрування. 2019. № 4 (90). C. $38-46$.

10. Тарасюк Г.М., Чагайда А.О., Соколовська I.О. Перспективні напрями розвитку готельного бізнесу для забезпечення фінансової стабільності індустрії гостинності України. Причорноморські економічні студіï. 2020. Вип. 55-2. С. 17-24. 
11. Що таке глемпінг та де його шукати в Україні? URL: https://veterdoit.com/shcho-takehlempinh-ta-de-yoho-shukaty-v-ukraini.

12. Намет $з$ кондиціонером та Wi-Fi: що таке глемпінг та чи $\epsilon$ він в Україні. URL: https://shotam.info/namet-z-kondytsionerom-ta-wi-fi-shcho-take-hempinh-ta-chy-ie-vin-v-ukraini.

13. Грановська В.Г., Бойко В.О. Функціонування екоготелів в Україні як чинник активізації підприємницької діяльності. Економіка АПК. 2020. № 3. С. 57-65. DOI: https://doi.org/10.32317/ 2221-1055.202003057.

14. Глэмпинг: в Украине появился новый бизнес, генерирующий прибыль. URL: http://derevo.ua/articles/details/glemping-v-ukraine-poyavilsya-novyj-biznes-generir-99.

15. Romanenko Y.O., Boiko V.O., Shevchuk S.M., Barabanova V.V., Karpinska N.V. Rural development by stimulating agro-tourism activities. International Journal of Management. 2020. № 11 (4). P. 605-613. DOI: 10.34218/IJM.11.4.2020.058.

16. Korchevska L., Zhosan G., Kavun S. Social Responsibility as a Contextual Component of the Enterprise Economic Security. Journal of Finance and Economics. 2013. Vol. 1. No. 4. P. 95-104. DOI: http://DOI:10.12691/jfe-1-4-6.

17. Kharazishvili Y., Kwilinski A., Grishnova O., Dzwigol H. Social Safety of Society for Developing Countries to Meet Sustainable Development Standards: Indicators, Level, Strategic Benchmarks (with Calculations Based on the Case Study of Ukraine). Sustainability. 2020. № 12. P. 8953. DOI: $10.3390 /$ su12218953.

18. Kwilinski A., Tkachenko V., Kuzior A. Transparent cognitive technologies to ensure sustainable society development. J. Secur. Sustain. 2019. Issue 9. P. 561-570. DOI: 10.9770/jssi.2019.9.2(15).

\section{References:}

1. Davydenko I.V. (2017) Hlempinh yak perspektyvna forma rozvytku ekoturyzmu [Glamping as a promising type of eco-tourism development]. Naukovyi visnyk mizhnarodnoho humanitarnoho universytetu [Scientific Bulletin of the International Humanitarian University]. Odesa: International Humanitarian University.Issue 26. P. 10-13.

2. Boiko V.O. (2021) Ecological tourism as a component of a green economy. Efektyvna ekonomika [Online], vol. 4. Available at: http://www.economy.nayka.com.ua/?op=1\&z=8773 (accessed 23 July 2021). DOI: 10.32702/2307-2105-2021.4.73.

3. Boiko V.O. (2020) Green tourism as a perspective direction for rural entrepreneurship development. Scientific approaches to modernizing the economic system: vector of development: collective monograph. Lviv Toruń: Liha-Pres, pp. 1-18. DOI: https://doi.org/10.36059/978-966-397-189-6/1-18.

4. Boiko V.O. (2020) Rural green tourism in Ukraine: problems and prospects. Agrosvit, vol. 22, pp. 58-65. DOI: $10.32702 / 2306-6792.2020 .22 .58$.

5. Boiko V.O. (2020), The development of green tourism in the southern region. Entrepreneurship in the agrarian sector: global challenges and effective management: Proceedings of the 1st International scientific practical conference in 2 parts (pp. 65-68). 12-13 liutoho 2020, Zaporizhzhia: ZNU.

6. Kyrylov Y., Hranovska V., Boiko V., Kwilinski A., Boiko L. (2020) International Tourism Development in the Context of Increasing Globalization Risks: On the Example of Ukraine's Integration into the Global Tourism Industry. Journal of Risk and Financial Management, no. 13(12), p. 303.

7. Lyulyov O., Us Y., Pimonenko T., Kwilinski A., Vasylieva T., Dalevska N., Polcyn J., Boiko V. (2020) The Link between Economic Growth and Tourism: Covid-19 Impact. In Khalid S. Soliman (Ed.). Proceedings of the 36th International Business Information Management Association (IBIMA) 4-5 November 2020 (pp. 8070-8086). Granada: IBIMA Publishing.

8. Boiko V.O., Drahota I.P. (2021) Glamping is an exclusive tourism product of the present. The 1st International Science Conference on Multidisciplinary Research, January 19-21, 2021, Berlin, pp. 208-210.

9. Oliinyk O.V., Mostenska T.L., Tarasiuk H.M., Chahaida A.O. (2019) Perspektyvy rozvytku hoteliv u styli hlempinh v Ukraini [Prospects of developing hotels in the style of glaming]. Ekonomika, upravlinnia ta administruvannia, no. 4 (90), pp. 38-46.

10. Tarasiuk H.M., Chahaida A.O., Sokolovska I.O. (2020) Perspektyvni napriamy rozvytku hotelnoho biznesu dlia zabezpechennia finansovoi stabilnosti industrii hostynnosti Ukrainy [Promising trends in the development of hotel industry to ensure financial stability of hospitality industry in Ukraine]. Prychornomorski ekonomichni studii. Issue 55-2. P. 17-24.

11. Shcho take hlempinh ta de yoho shukaty v Ukraini [What is glamping and where it can be found in Ukraine]. URL: https://veterdoit.com/shcho-take-hlempinh-ta-de-yoho-shukaty-v-ukraini (accessed 20 March 2021). 
12. Namet $\mathrm{z}$ kondytsionerom ta Wi-Fi: shcho take hlempinh ta chy ye vin $\mathrm{v}$ Ukraini [A tent with an air-conditioner and Wi-Wi: what is glamping and if it is available in Ukraine]. URL: https://shotam.info/namet-z-kondytsionerom-ta-wi-fi-shcho-take-hempinh-ta-chy-ie-vin-v-ukraini (accessed 20 March 2021).

13. Hranovska V.H., Boiko V.O. (2020) Funktsionuvannia ekohoteliv v Ukraini yak chynnyk aktyvizatsii pidpryiemnytskoi diialnosti [Functioning of eco-hotels in Ukraine as a factor of activization of entrepreneurial activity]. Ekonomika APK, no. 3, pp. 57-65. DOI: https://doi.org/10.32317/2221-1 055.202003057. (in Ukrainian)

14. Glemping: v Ukraine poyavilsia novyy biznes generiruyushchiy pribyl' [Glamping: a new business has appeared in Ukraine that generates profits]. URL: http://derevo.ua/articles/details/glemping-v-ukraine-poyavilsya-novyj-biznes-generir-99 (accessed 12 July 2021).

15. Romanenko Y.O., Boiko V.O., Shevchuk S.M., Barabanova V.V., Karpinska N.V. (2020) Rural development by stimulating agro-tourism activities. International Journal of Management, no. 11 (4), pp. 605-613. DOI: 10.34218/IJM.11.4.2020.058.

16. Liliya Korchevska, Ganna Zhosan, Sergii Kavun (2013) Social Responsibility as a Contextual Component of the Enterprise Economic Security. Journal of Finance and Economics, vol. 1, no. 4, pp. 95-104. DOI: http://DOI:10.12691/jfe-1-4-6.

17. Kharazishvili Y., Kwilinski A., Grishnova O., Dzwigol H. (2020) Social Safety of Society for Developing Countries to Meet Sustainable Development Standards: Indicators, Level, Strategic Benchmarks (with Calculations Based on the Case Study of Ukraine). Sustainability 2020, 12, 8953, DOI: $10.3390 /$ su12218953.

18. Kwilinski A., Tkachenko V., Kuzior A. (2019) Transparent cognitive technologies to ensure sustainable society development. J. Secur. Sustain. Issues 2019, no. 9, pp. 561-570. DOI: 10.9770/ jssi.2019.9.2(15). 